\title{
Love Theme of Contemporary Russian Works of Narbikova in Post-modernism Style
}

\author{
Kai Zhu \\ School of Literature and Media \\ Shanghai University of Political Science and Law \\ Shanghai, China
}

\begin{abstract}
This paper expounds the characteristics of postmodernism style in contemporary Russian female literature narrative and attempts to make a comprehensive and objective sorting and analysis on the love theme of Narbikova's works based on the viewpoints and methods of literary theory. Narbikova looked at females living in the bottom level of real life using her wise and gentle eyes based on a unique perspective and life experience and told their love anxiety and marriage misfortune.
\end{abstract}

Keywords—post-modernism style; contemporary Russia; Narbikova; love theme

\section{INTRODUCTION}

Post-modernism literature is a new literature ideological trend in contemporary Russian literature, while female literature was right emerged in the most prosperous period of post-modernism literature. Works of Narbikova mostly focused on a series of complicated and difficult problems that Russian female was confronting with such as living, love, marriage and children and so on, attracted readers' introspection and attention on the entire society. Her writing was influenced by the post-modernism ideological trend. She widely applied post-modernism creation method in her works, realizing the destruction and subversion against traditional classic literature. In the portrayal of characters, she also brake and rebuilt the traditional characters in Russian literature.

\section{POST-MODERNISM STYLE}

In thoughts and ideas, post-modernism has strong nihilism tendency. It is contrary to all existing values and artistic views and traditionally refuses the literature view of elitism. Emotionally, it expresses the anger, loneliness, sense of crisis as well as sense of loss in spirit and feeling of tension in reality that are hard for partial writers to dispel. Post-modernism humanism completely abandons the humanoriented thinking, rejects the simplification, patterning and idealization of human beings but regard people as a physical, sensory, conscious and unconscious unity to reveal the multilever nature of people in reality.

The characters in postmodernism novels are abnormal, pathetic, ill-fated, and defective peoples who lived in the fringe of the history, characterized by lack of personality, abnormality in character, heresy in behavior, moral defects and mental closure. Such novels no longer tell story, no longer narrate, no longer pays attention to image, type, personality, plot structure and aesthetic taste and so on but become a struggle in words and expressions, an accumulation of means gone nowhere and a hodgepodge involving different ideas and mental fields but lack of uniform content. Meanwhile, post-modernism is opposed to abide by any single aesthetic principle. Post-modernism believed that "the world is chaos", "the world is the text" and "consciousness is the text". In response to those thoughts, intertextuality, author's masks, double coding, parody and fragmentary narratives and so on became the most favorite creative methods of post-modernism.

The disintegration of Soviet Union objectively provided the most suitable soil for the emerging of post-modernism ideological trend. Post-modernism penetrated into in Russia in all aspects of cultural life in accelerated speed and occupied prominent position in the diversified literary pattern, posing influence on writing of many writers. In contemporary Russian female literature, most writers having post-modern style were relatively young and entered the literary world in mid-1980s. Both female writers and male writers of post-modernism style used some typical postmodernism expression skills in their works, such as intertextuality, parody, collage, irony, deconstruction and games. This paper tries to take novels of Narbikova as the main object to explain and analyze the post-modernism style in contemporary Russian female literature.

\section{BREAKING THROUGH THE TRADITION AND BELIEVING IN ETERNAL LOVE}

In love-themed literature works in contemporary Russian female literature, basic passion of people was affirmed and the content of sex entered into the creation of many female writers with an unprecedented potential and strength, forming into an important aspect in female love themed novels.

Narbikova is one of the female writers involving sexual content in her writings in the earliest time and was thought the most prominent person among those who destroyed the 
linguistic rhetoric and moral peace ${ }^{1}$. In 1988, she published a novellas maiden work "Balance of variation among sun, moon and star" in the Russian magazine "Youth". This postmodern styled novel depicting the love between two men and one woman posed two distinct views in Russian critics circle. Those represented by writer Andrei Bitov believed that this work is "surprisingly penetrating and fascinating", ${ }^{2}$ while those represented by Dmitriy Urnov hold that this work lacks philosophical depth and is thus a "bad novel" and "erotic novel" ". However, the critics circle seems to have reached some consensus that this work of Narbikova is amazing and interesting in unsatisfied sex and physiology. Narbikova included in her novel those sexual scenes avoided in traditional Russian literature (especially in Soviet literature) and some contents previously difficult to be defined as art. Her sexual descriptions full of hints and symbolic words indeed produced sensational effect in Russia. Some other novels of Narbikova such as the novella "Escape - about running" (1990) and "Hell is yes, yes is prison"4 (1991) and the long-length novel "Travel" (1996) and etc. have many common points with the "Balance of variation among sun, moon and star" both in language patterns (repetition of synonyms) and plot patterns (taking the triangle love as the main content).

In the novel "Balance of variation among sun, moon and star" which can be called master work of Narbikova, Narbikova describes ${ }^{5}$ the complex relationship between several couples of men and women. With respect to the double identity of protagonist acting as both wife/husband and lover, it is written at the beginning of the novel that "For love, you need to abide by the three-in-one principles, namely to maintain uniformity in time, place and event." ${ }^{16}$ The heroine Sana and her lover Atmat Fian both have their own families. After several times of making-up and breaking-up, they both go back to their own husband/wife. In the novel, there are many descriptions of sexual scenes and the dialogues among characters are also full of ambiguous sex implication. However, Narbikova' description of sex is not simply for purpose of "destroying the tradition", not for writing about sex, but try to give sex a more profound meaning which is also the deeper meaning of his novel. In "Balance of variation among sun, moon and star", the narrator emphasizes the unity of spirit and body: when two people are combined together, it is "one person having two

Najzhda Azhisina. The destroyer in the exploration of faith: a new feature of contemporary youth novels, New World, Russia, No. 4, 1988, p223.

Andrei Bitov. An introduction to Narbikova's novel, Youth, Russia, No.8, 1988, p15.

Urnov. A bad novel, Literary Newspaper, Russia, Feb.8, 1989, 4 th edition.

In the original text, the title of the novel "Ад как Да, аД как дА" can be read from right to left and also can be read from left to right. Both reading manners will get the same result. Therefore in English, the title is translated in the same way. p67.

Narbikova. Escape — about running, Flag, Russia, No.5, 1990,

6 Narbikova. Balance of variation among sun, moon and star, Female Logic, (editor in chief: Lyudmila stepanenko), Soviet Modern Press, $1989, \mathrm{p} 479$. heads... she rotates around him and he rotates around her." 7 At the same time, this unification of spirit and body can overcome the ecological anxiety of human beings. Everyone is a part of nature since birth. But in the shield-like life, people gradually forget their natural attribution and tries to transform and tame the nature. In the meaningless effort on nature, people have always been destroying the nature. It is believed that only the kind of love that combines spirit and body can make the earth lasting forever so that human beings can see the connection between themselves and nature: "When Sana kisses Atmat Fian, Sana and Atmat Fian would become a part of the sky. In this place, the body of destroyed earth beautiful and terrible is better than just having a good quality sky... and the body of earth untouched would become better doubled. ${ }^{8}$ In Narbikova's novel, everything is fleeting. Only the kind of spirit and body combined can surpass all time and space and finally survive." In her another novella, "Beside", Narbikova describes the beautiful sexual love between the girl Petya and Boris: "They merge into one. The fusion point is not in the street garden, not in the cinema but in the gentlest point. At that point, it was hot and hot and cannot be expressed in words. " ${ }^{9}$ For them, "The revolution has come and gone. It only leaves flags, prisons and monuments. The idols have come and gone. It only leaves a monument like prison" and "Everything will pass away, everything will change. Only beauty will stay (artwork and architecture), no, a poet once said that only love will leave". ${ }^{10}$ As described in the novella "Escape — about running", when the hero and heroine "touch each other, the front page of Pravda is out of date, because another year and another day is beginning"11. In Narbikova's writing, the love of the hero and heroine is filled with the fusion of sex and this spirit and body combined love can transcend time and space and transcend material, becoming an eternal presence.

\section{DECONSTRUCTION CONCEPT AND GAME-LIKE TEXT}

Narbikova is a member of contemporary Russian female writers who have always adhered to post-modern positions. Her creations have always been in distinctive post-modern style. Narbikova's works are complicated and incomprehensible. It is even not available to summarize her narrative content. Her work can be read from any place, or ended in any place. In her work, there is neither close logical relationship nor any coherent plot clues. The space of her novel is stretched out and drawn back alternatively unceasingly and the characters are constantly appearing and disappearing in various time and space. This makes the already very vague plot clues more difficult to grasp and adds difficulty for readers to read. As it were, Narbikova's novel is like a game that she plays with reader. She does not want the reader to decipher her own works or to give a unique interpretation on her works. Therefore, she keeps on setting up various traps in order to prevent readers' attempt to

$\begin{aligned} 7 & \text { Ditto, p480. } \\ 8 & \text { Ditto, p484. } \\ { }^{9} & \text { Narbikova. Escape — about running, Flag, Russia, No.5, 1990, } \\ \text { p67. } & \\ 10 & \text { Ditto, p19. } \\ 11 & \text { Ditto, p67. }\end{aligned}$


interpret her works. For example in her novella "Balance of variation among sun, moon and star", the names of two boy friends of the heroine Sana are respectively Аваакум (named after the name of leader of a splinter group in Russia) and Atmat Fian (named after Matthew, the name of one of the twelve apostles of Jesus). But in her work, the intertextual connection created with Аваакум and Matthew is useless to understand personalities of the character. If reader is insistently to create a certain connection between them, the reader will only get stuck in the trap deeper and deeper. As in her other novels, the names of characters in this novel are just false hints useless for interpreting the work. In Narbikova's works, everything is interchangeable. Characters, scenes, spaces and even different historical periods have ever been changed in positions in her novels. For instance, Pushkin and Lermontov might live at the present (see her "Escape - about running"); characters's gender might be changed, namely, they might become women in front of men and become men in front of women (see her "Hell is yes, yes is prison"); they might also lose gender (see her "Balance of variation among sun, moon and star"); the five senses of characters might also be changed in positions and replaced with each other (see her "Hell is yes, yes is prison"). The hierarchy between people and things are lost and everything can be combined together side by side. As said by the protagonist in her "Balance of variation among sun, moon and star", "We love each other, like we love puppy, potato, mother, sea, beer, a pleasing little girl, underwear, a book, a playboy and Tyutchev." ${ }^{12}$ This sentence is the best proof of the disappearance of hierarchy between people and things. In her works, noble and vulgar can be combined together: "He eats, drinks, does not sleep and even makes love while listening to the opera 'Carmen' ; but it is unknown as to what kind of opera that Carmen listens to when making love. "13 Making the high-level content mediocre is also a writing method of Narbikova. For example in the "Balance of variation among sun, moon and star", she regards the threein-one principles (i.e., the uniformity in time, place and event) as the prerequisites for heroine and lover to date and compares the powerless state of men after making love to the fallen palms as said in the Lermontov's poem "Three Palms". All the interchangeability and hierarchical disappearance between people and things as well as the blurring of boundaries between high-level culture and low-level culture are a deconstruction against the concept of traditional culture, Narbikova's attempt to play games of text and previous literary norms and styles and more of her efforts attempting to prevent reader from making a single interpretation on her works.

\section{SIMPLE EXPRESSIONS AND REPETITION OF SYNONYMS}

The linguistic features of Narbikova's works are also prominent. In her text, there are no complex expressions and

\footnotetext{
12 Narbikova. Balance of variation among sun, moon and star,
}

Female Logic, (editor in chief: Lyudmila stepanenko), Soviet Modern Press, 1989, p479.

13 Narbikova. Escape - about running, Flag, Russia, No.5, 1990, $\mathrm{p} 75$. sentence patterns. Adjectives and modifiers only appear when they are essential to be used. She gets literary language, folk adage, slang and even swear words mixed together, breaking all grammatical rules and treats the language as a toy that she can arbitrarily use. Various unexpected combinations and matching emerge in her novels endlessly, while those contents are very difficult to be expressed or translated in another language. Even the names of her works also become a part of her language game. For example, the title of her novella "Hell is yes, yes is prison" not only arrogates grammar and discourse rules but also has visual impact. It can be read both from left to right and from right to left and the meanings are the same. Repetition of synonyms, that is to say that the same expression or the expressions of identical meaning appears in a sentence repeatedly, is another distinctive feature of the Narbikova's writing.

"If Petya was still the Petya who loves Boris, or if Boris was still the poor Boris but become rich, then Yitz Dan Dukta would not be the Yitz Dan Dukta who once loved Boris but be another Yitz Dan Dukta who would be satisfied by another man different absolutely." This sentence contains the names of all protagonists in the novel "Beside". Wherein, the names have been separated from their masters and become the indirect roles of the heroine "I" in various statuses.

\section{CONCLUSION}

Compared with the new-naturalism style and newsentimentalism style, the influence generated by post-modern style of contemporary Russian female writer Narbikova is relatively weak. If it was said that female writers have acquired their own unique expression techniques and theme fields from new-naturalism and new-sentimentalism styles, then in post-modern style creation, she does not show a clear distinction with male writers but only be one of the many players in the post-modernism trend and does not leave a very deep impression in mind of readers.

Russian critic Vikuricen once said that contemporary Russian literature has entered into the post-modern period ${ }^{14}$. Although the post-modern style does not "monopolize" the literary world as he said and the public's response to has become increasingly dull in recent years, what cannot be ignored is that this style has been permeated into every level of literature and posed considerable influence on many styles and genres. Post-modernism is a deconstruction of the previous literary image and content. It is a proof of the writer's practice of creation in multiple styles and a demonstration of literary pluralism. Writers are expected to show their talents in various styles of literary works and leave their own phonetic symbols in the multi-voice literary chorus.

\footnotetext{
14 Najzhda Azhisina (11.A-mIIa). The destroyer in the exploration of faith: a new feature of contemporary youth novels, New World, Russia, No. 4, 1988, p223.
} 


\section{REFERENCES}

[1] Mu Chonghuai. An analysis of the gender image category in contemporary Russian female literature, Journal of Liaoning University (Philosophy and Social Sciences Edition), No.1, 2017.

[2] Zhang Lei. Research on sentimental naturalism style in Petrushevskaya's novel, Journal of Sichuan International Studies University (Master's Thesis), April, 2017.

[3] Wang Wei. Creative theme of Russian female literature, Journal of Qiqihar Junior Teachers' College, No.6, 2017. 